\title{
Diversity of sand flies in domiciliary environment of Santarém, state of Pará, Brazil: species composition and abundance patterns in rural and urban areas
}

\author{
Marlisson Augusto Costa FEITOSA¹, Genimar Rebouças JULIÁO² ${ }^{2}$, Manoel Djalma Pereira COSTA³, Braulio \\ BELÉM $^{3}$, Felipe Arley Costa PESSOA ${ }^{2}$
}

\begin{abstract}
This paper aimed to evaluate the richness, abundance and frequency of sand fly occurrence in rural and urban areas American visceral leishmaniasis -AVL is endemic in the study area of Santarém municipality, Pará state. Sand flies were collected during 1995-2000, using CDC light traps placed in neighborhoods and rural areas of the municipality. A total of 53.454 individuals and 26 species of sand flies were collected. The most abundant species in both urban and rural environments was Lutzomyia longipalpis, vector of AVL in the area. The highest species richness by capture was in rural area. In all years sampled, the largest number of species of sand fly collected was always in rural areas. The species of sand flies in urban and rural area were similar in 11 species. In the rural area other 11 species were found, a total of 22 species. Shannon-Wiener index ranged from 0.12 to 0.84 at rural areas and 0.08 to 0.34 at urban ones. In general, rural localities showed higher diversity $\left(H^{\prime}\right)$ of phlebotomines than urban ones. Individual-based rarefaction curves for each area demonstrated that urban localities had the lowest expected number of phlebotomine species and the richest rural ones reach higher expected values with lower amount of individuals than urban sites. The most frequent species were Lutzomyia longipalpis, Evandromyia carmelinoi and Bichromomyia flaviscutellata.
\end{abstract}

KEYWORDS: leishmaniasis, anthropic impact, Amazon

\section{Diversidade de flebotomíneos no ambiente domiciliar de Santarém, estado do Pará, Brazil: composição de espécies e padrões de abundância em áreas urbanas e rurais}

\section{RESUMO.}

Com o objetivo de comparar a riqueza, abundância e freqüência de ocorrência de flebotomíneos em sítios rurais e urbanos numa área endêmica de leishmaniose visceral no município de Santarém (PA) foi realizado no período entre 1995-2000, capturas de flebotomíneos por meio de armadilhas luminosas CDC montadas no ambiente domiciliar em diferentes bairros e localidades rurais do município. Foram capturados 53.454 indivíduos, de 26 espécies e dentre elas, a mais abundante, tanto em ambiente urbano e rural, foi Lutzomyia longipalpis, vetor da leishmaniose visceral americana na região. Em todos os anos de amostragem, a maior riqueza de espécies por captura foi obtida em áreas rurais. As áreas rurais e urbanas compartilharam onze espécies de flebotomíneos; enquanto este mesmo número de espécies foi exclusivo em áreas rurais. Os índices de ShannonWiener variaram de 0,12 a 0,84 nas localidades rurais e de 0,08 a 0,34 nas áreas urbanas. Em geral, as áreas rurais apresentaram maior diversidade de flebotomíneos comparado às áreas urbanas. As curvas de rarefação baseadas em indivíduos revelaram um rápido aumento no número esperado de espécies em localidades rurais, indicando que amostras com menor quantidade de indivíduos nestas áreas atingem maior riqueza de espécies. As espécies mais freqüentes durante o período de amostragem foram Lutzomyia longipalpis, Evandromyia carmelinoi e Bichromomyia flaviscutellata.

PALAVRAS-CHAVE: leishmanioses, antropização, Amazônia

\footnotetext{
1 Instituto de Ciências e Tecnologia das Águas, Universidade Federal do Oeste do Pará Av. Vera Paz, s/nº Salé, CEP 68135-110 - Santarém - PA. marlisson.feitosa@gmail.com

2 Programa de Pesquisa em Ecologia de Doenças Transmissíveis na Amazônia PPEDTA; Instituto Leônidas e Maria Deane, Fiocruz, Rua Terezina, 476. Adrianópolis. CEP: 69.057-070 Manaus, AM. facpessoa@amazonia.fiocruz.br

${ }^{3}$ 9Centro Regional de Saúde; Divisão de Endemias - Avenida Marechal Rondon, № 1638, Bairro Santa Clara - CEP: 68005-120 - Santarém - PA. manoeldjalma@yahoo.com.br
} 


\section{INTRODUCTION}

Sand flies are insects of medical and veterinary importance once some species are able to transmit several pathogens such as Bartonella spp., Phlebovirus spp., and several trypanosomatids, as well-known, Leishmania spp. There is a higher richness pattern of sand flies in the Amazon region (Young and Duncan 1994; Barrett et al. 1996). Nevertheless, studies of Amazonian sand fly species generally are restrict to some few descriptive studies related to epidemiological surveys or vertical and horizontal stratification. In Latin America, leishmaniasis represents a great threat to human health, since this disease has been pointed out as an emergent disease due to environmental changes mainly caused by road construction and timber extraction (Patz et al. 2004). In Brazil populations exposed to leishmaniasis are not only inhabitants of rural areas but also miners, hunters, and some periurban populations of some cities (Barrett 1993). Sand fly species domiciliation can result in the occurrence of urban leishmaniasis, as noticed by cases record in the periphery of some Brazilian metropolis (Teodoro et al. 1999; Rêbelo 2001; Carvalho et al. 2010; Saraiva et al. 2011).

As several cities in northern Brazil, Santarém municipality, state of Pará, has grown in area and population, with a disordered expansion during the last twenty years (Furtado and Macedo 2006). The first record of American visceral leishmaniasis (AVL) in Santarém was reported by Alencar et al. (1962) who found three autochthon cases of AVL in human and 19 cases in dogs. In the 1990's were recorded 58 cases of human AVL (Pereira et al. 2000) and 177 cases were reported in the past ten years (2001-2010), demonstrating that the problem increased. Concerning the American cutaneous leishmaniasis (ACL), the Zoonosis Control Center of Santarém reported a monthly average of 52 cases of ACL (data base from 1998 to 2003) in the total amount, at least 17 cases were autochthonous from the peripheral neighborhoods of Santarém (Feitosa and Castellón 2009).

In concluding remarks of the Brazilian ACL and AVL Control Program, Lacerda (1994) pointed out the need of more precise data on vector biology to elaborate effective control measures. Currently, risk estimates of leishmaniasis transmission are still very poor due to the lack of parameters based on vector presence, its abundance, and infestation level in a given habitat (Maia-Elkhoury et al. 2008). However, the evaluation of species abundance patterns should allow inferences about some ecological aspects as local population size, rarity, and dominance of species, endemicity, and habitat specialization (Magurran 2004). In addition to relative abundance index, the frequency of occurrence (percentage of samples in which species are present) constitutes an easy and feasible tool to understand alterations in vector (and other organisms) populations due to man-made environment perturbation (Pessoa et al. 2007; Odum and Barrett 2007).

The present study aimed to answer the following questions: (i) sand fly richness and abundance per capture event differ between urban and rural areas?; (ii) diversity, dominance and estimated richness of sand flies differ between urban and rural areas? How similar is the phlebotomine fauna comparing one area to another? (iii) the frequency of occurrence (along sampling period) of sand fly species are the same to these areas? Some implications of sand fly abundance patterns were discussed in the light of leishmaniasis transmission.

\section{MATERIALS AND METHOD}

\section{Study area}

The study was carried out by the Epidemiological Surveillance team of the Department of Entomology, State Public Health Secretary of Pará (SESPA, 9 Regional de Endemias), in the period among 1995-2000, in Municipality of Santarém $\left(02^{\circ} 26^{\prime} S\right.$ and $\left.54^{\circ} 42^{\prime} \mathrm{W}\right)$, state of Pará, Brazil (Figure 1).

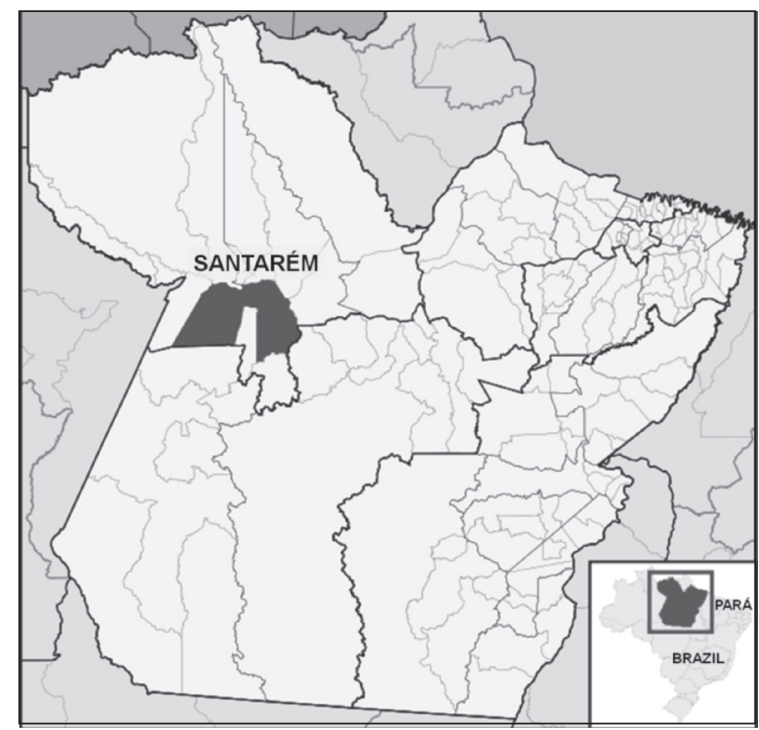

Figure 1 - Location of Santarém municipality, state of Pará, Brazil (Adapted from Campos 2006).

Regional climate is Am and Amw type by the Köppen classification, a rainy climate with precipitation above 2,000 $\mathrm{mm}$ and short dry season (Furtado and Macedo 2006). The mean annual temperature ranges from $25^{\circ} \mathrm{C}$ to $28^{\circ} \mathrm{C}$, with rainy season between December and May, maximum precipitation levels usually are observed in February. A tropical rain forest is the predominant vegetation in Santarém, except for Amazonian savannas found in the northwestern area of the municipality. 


\section{Sand fly capture}

Insect sampling collections were carried out between 1995 and 2000, as routinely activities of endemic AVL Control Program conducted by SESPA in the Santarém municipality. Captures of sand flies were performed weekly, in all localities/ districts which registered visceral leishmaniasis cases in human or dog population. At each locality/district, ten houses were randomly chosen and a CDC light trap was placed inside the dormitory room and another one in peridomiciliar area (near to domestic animal shelters) in each house. Traps were kept on during two consecutive nights. Sand fly specimens were identified according to Ryan (1986) and nomenclature was adopted according to Galati (2003).

\section{Data analyses}

In the present study, species richness and abundance of individuals were counted by the number of sand fly species and total number of individuals captured in a given area (urban or rural) or year, respectively. Since sampling efforts varied among years and areas, richness and abundance were divided by the total number of capture events (traps) carried out at one area/year. Mann-Whitney test was used to verify possible differences between urban and rural areas with respect to sand fly abundance and richness per capture event. Shannon-Wiener diversity index $(H)$, Berger-Parker dominance index $(d)$, estimated richness of phlebotomines ( $\mathrm{S}_{\text {Chao } 1}$ bias-corrected) and their lower and upper confidence limits (95\%), and Sørensen similarity index $\left(C_{s}\right)$ were computed to each sampling year (Magurran 2004, Colwell 2009). Individualbased rarefaction curves (with 95\% confidence intervals) were employed to estimate and compare the expected number of species in urban and rural areas (Gotelli and Colwell 2001). The variable frequency of occurrence (species presence along sampling period) was based on the ratio between the number of years that a given sand fly species occurred and total period sampling (six years) and expressed as percentage. Species captured in only one or two years along the study $(0-25 \%$ frequency class) were defined as rare; moderately common species (hereafter, only common species) were sampled in three or four years of the study (26-75\% frequency class) and very common species were collected in five years of study or all years (76-100\% frequency class) (Gray et al. 2005).

\section{RESULTS}

It was collected 53,454 sand fly specimens in a six-year long study, belonging to 26 species. In urban areas, 38,832 individuals were caught, which represented about 2.5 fold of sand fly individuals captured in the rural localities $(14,622$ individuals) of Santarém. The most numerous and frequent species were Lutzomyia longipalpis and Evandromyia carmelinoi, comprising together $\approx 99 \%$ of total individuals sampled in both areas (Table 1).

Table 1 - Number of sand fly individuals captured along six consecutive years in houses at urban and rural areas of Santarém municipality, state of Pará, Brazil.

\begin{tabular}{|c|c|c|}
\hline Sand fly Species & Urban Area & Rural Area \\
\hline Lutzomyia longipalpis (Lutz and Neiva) ‡ & 37,389 & 13,583 \\
\hline Evandromyia carmelinoi Ryan, Fraiha, Lainson and Shaw & 1,320 & 643 \\
\hline Nyssomyia whitmani (Antunes and Coutinho) $†$ & 56 & 107 \\
\hline Bichromomyia flaviscutellata (Mangabeira) $†$ & 39 & 65 \\
\hline Micropygomyia rorotaensis (Floch and Abonnenc) & 9 & 41 \\
\hline Nyssomyia antunesi (Coutinho) & 5 & 19 \\
\hline Brumptomyia avellari (Costa Lima) & 3 & 24 \\
\hline Nyssomyia umbratilis (Ward and Fraiha) † & 3 & 4 \\
\hline Lutzomyia gomezi (Nitzulescu) & 2 & 8 \\
\hline Psychodopygus davisi (Root) † & 1 & 8 \\
\hline Micropygomyia trinidadensis (Newstead) & 1 & 3 \\
\hline Nyssomyia shawi Fraiha, Ward and Ready & 1 & 0 \\
\hline Trichopygomyia trichopyga (Floch and Abonnenc) & 1 & 0 \\
\hline Micropygomyia oswaldoi (Mangabeira) & 1 & 0 \\
\hline Brumptomyia travassosi (Mangabeira) & 1 & 0 \\
\hline Trichophoromyia castanheirai (Damasceno, Causey and Arouck) & 0 & 76 \\
\hline Psathyromyia aragaoi (Costa Lima) & 0 & 21 \\
\hline Viannamyia tuberculata (Mangabeira) & 0 & 5 \\
\hline
\end{tabular}


Table 1 - Continuation

\begin{tabular}{lcc}
\hline Sand fly Species & Urban Area & Rural Area \\
\hline Evandromyia evandroi (Costa Lima and Antunes) & 0 & 4 \\
Trichopygomyia longispina (Mangabeira) & 0 & 3 \\
Trichopygomyia dasypodogeton (Castro) & 0 & 3 \\
Viannamyia furcata (Mangabeira) & 0 & 1 \\
Psychodopygus wellcomei (Fraiha, Shaw and Lainson) † & 0 & 1 \\
Trichophoromyia ubiquitalis (Mangabeira) † & 0 & 1 \\
Evandromyia pinotti (Damasceno and Arouck) & 0 & 1 \\
\hline Psychodopygus ayrozai (Barretto and Coutinho) & 0 & 14,622 \\
\hline Total & 38,832 & \\
\hline
\end{tabular}

† Main or putative vectors of American cutaneous leishmaniasis (ACL) in northern Brazil. ‡ Main vector of American visceral leishmaniasis (AVL) in northern Brazil.

\section{Urban $x$ rural areas}

Despite higher number of individuals in urban sites, rural areas showed more sand fly species (22 versus 15 species) and a higher richness per capture event $(U=0.0, p=0.004$, Figure 2a). Although no significantly difference was observed between the areas in relation to the abundance per capture event $(\mathrm{U}=8.0$, $\mathrm{p}=0.109$ ), a higher number of specimens was captured in each event in rural areas compared to urban ones, in the majority of sampled years (Figure $2 \mathrm{~b}$ ).

\section{Diversity, dominance, observed and estimated richness, and similarity}

The Shannon-Wiener index ranged from 0.12 to 0.84 at rural areas and 0.08 to 0.34 at urban ones. In general, rural localities showed higher diversity $(H)$ of phlebotomines than urban ones, except by the year 1998. Inverse pattern
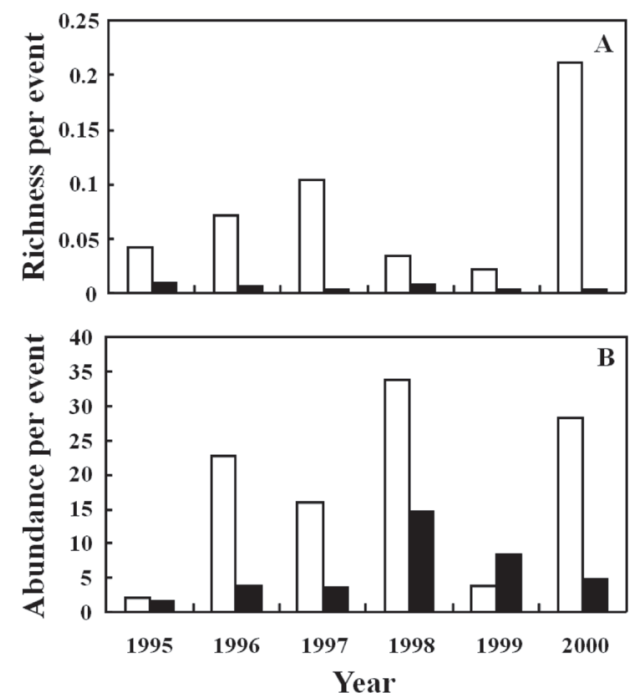

Figure 2 - Sand fly richness (a) and abundance (b) per capture event in rural (white bars) and urban (black bars) in the six-year sampling, at Santarém municipality, state of Pará, Brazil. was observed to Berger-Parker index $(d)$ in rural areas, which usually presented lower dominance of the most abundant species (L. longipalpis) than urban localities. We also observed differences between observed and estimated richness (Chao1, bias corrected) due to presence of singletons (species represented by one individual) and doubletons (species represented by two individuals) in some years; however these differences occurred with the same frequency in urban and rural areas. Similarities in the species incidence at urban and rural areas varied from 0.38 to 0.60 ; however almost all years had values around 0.50 , except for 1998 (Table 2). Confidence intervals of individual-based rarefaction curves for each area clearly demonstrated that urban localities had the lowest expected number of phlebotomine species and the richest rural ones reach higher expected values with lower amount of individuals than urban sites (Figure 3).

\section{Shared and exclusive x rare, common, and very}

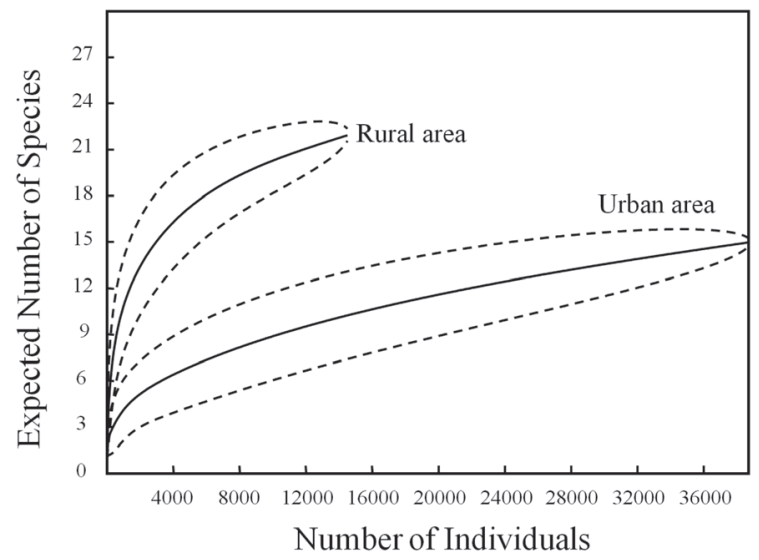

Figure 3 - Individual-based rarefaction curves for phlebotomine species in urban and rural areas at Santarém municipality, state of Pará, Brazil. 
Table 2 - Number of sampled localities, number of traps, Shannon-Wiener diversity index ( $\left.H^{\prime}\right)$, Berger-Parker dominance index $(d)$, observed ( $\left.S^{\text {obs }}\right)$ and estimated richness of phlebotomines $\left(S^{\text {Chao }}\right)$ ), lower and upper confidence limits $(95 \%)$, and Sørensen similarity index $\left(C^{S}\right)$ of species between urban and rural areas of Santarém municipality, state of Pará, Brazil.

\begin{tabular}{|c|c|c|c|c|c|c|c|c|}
\hline Year & Area & Localities & Traps & $\mathrm{H}^{\prime}$ & $d$ & $\mathrm{~S}_{\text {obs }}$ & $\mathrm{S}_{\text {Chao } 1}$ & $\mathrm{C}_{\mathrm{S}}$ \\
\hline \multirow{2}{*}{1995} & Urban & 122 & 607 & 0.33 & 0.93 & 6 & $6.0(6.0-6.0)$ & \multirow{2}{*}{0.50} \\
\hline & Rural & 59 & 326 & 0.84 & 0.82 & 14 & $17.0(14.4-37.0)$ & \\
\hline \multirow{2}{*}{1996} & Urban & 13 & 962 & 0.08 & 0.99 & 7 & $7.3(7.0-13.0)$ & \multirow{2}{*}{0.57} \\
\hline & Rural & 12 & 195 & 0.26 & 0.95 & 14 & $15.5(14.1-29.1)$ & \\
\hline \multirow{2}{*}{1997} & Urban & 19 & 1700 & 0.13 & 0.97 & 7 & $13.0(8.0-44.4)$ & \multirow{2}{*}{0.53} \\
\hline & Rural & 03 & 86 & 0.40 & 0.92 & 9 & $9.0(9.0-9.0)$ & \\
\hline \multirow{2}{*}{1998} & Urban & 15 & 1132 & 0.16 & 0.97 & 10 & $11.0(10.1-20.7)$ & \multirow{2}{*}{0.38} \\
\hline & Rural & 03 & 177 & 0.12 & 0.98 & 6 & $6.5(6.0-14.3)$ & \\
\hline \multirow{2}{*}{1999} & Urban & 13 & 797 & 0.10 & 0.98 & 3 & $3.0(3.0-3.0)$ & \multirow{2}{*}{0.60} \\
\hline & Rural & 16 & 323 & 0.62 & 0.82 & 7 & $7.0(7.0-7.0)$ & \\
\hline \multirow{2}{*}{2000} & Urban & 22 & 1076 & 0.34 & 0.90 & 4 & $4.0(4.0-4.0)$ & \multirow{2}{*}{0.55} \\
\hline & Rural & 01 & 33 & 0.75 & 0.75 & 7 & $7.0(7.0-7.0)$ & \\
\hline
\end{tabular}

\section{common species}

Besides higher sand fly richness, rural areas also presented higher number of exclusive species (11 species) while urban sites had only four species. These two habitats shared eleven Phlebotominae species. It was observed that exclusive species (to rural or urban areas), such as Psychodopygus wellcomei and Trichophoromyia ubiquitalis usually tended to have lower frequency of occurrence and smallest values of relative abundance (Figures 4 and 5). These rare species were sporadically sampled, in only one or two years $(0-25 \%$ occurrence class) of the study and with scarce number of specimens. Nevertheless, some sand fly species did not fit in this pattern. For instance, Trichophoromyia castanheirai, exclusive to rural areas, was a common species, and occurred in four of the six years of study.

Except for the dominant species L. longipalpis and $E$. carmelinoi, T. castanheirai presented a great relative abundance (Table 1, Figure 4 and 5). In opposite trend, shared species like L. longipalpis, E. carmelinoi and Bichromomyia flaviscutellata were the most frequent, very common species (75-100\% of occurrence) in the study, and caught in at least five sampling years. Another general tendency was that all species shared by rural and urban areas were trapped on higher numbers at the former area, like Nyssomyia whitmani and $N$. antunesi (Table 1).

\section{DISCUSSION}

In the present study, we observed an intrinsic abundance pattern to each sand fly species, which is related to aspects of its behavior, ecology and mainly, to differential capacity of adaptation to changes in urban and rural environments.

Higher sand fly richness per capture event in rural areas were not unexpected, once these insects are usually associated to forested areas (Aguiar and Medeiros 2003), and in northern Brazil, rural areas still have contact with extensive areas of primary forests or forest remnants. Conversely, no statistical difference between rural and urban areas was observed in the abundance per capture event, probably related to great variability in the number of sand fly specimens collected in each sample. Even so, the results suggested that more sand fly individuals/trap was caught in the rural sites, except by 1999 sample, which an inverse pattern was obtained. Furthermore, rural localities had a more diverse phlebotomine fauna: Shannon index averaged to each area were 2.5 fold larger in rural areas than urban ones and the expected number of species reached higher values with less individuals (compared to urban areas) in the rarefaction method; the last one, removes the effects of unequal sampling efforts (Gotelli and Colwell 2001).

Few studies compared simultaneously sand fly diversity between Brazilian urban and rural areas in a long time series. Our results showed a moderate overlapping in the species composition at rural and urban areas; the Sørensen index 


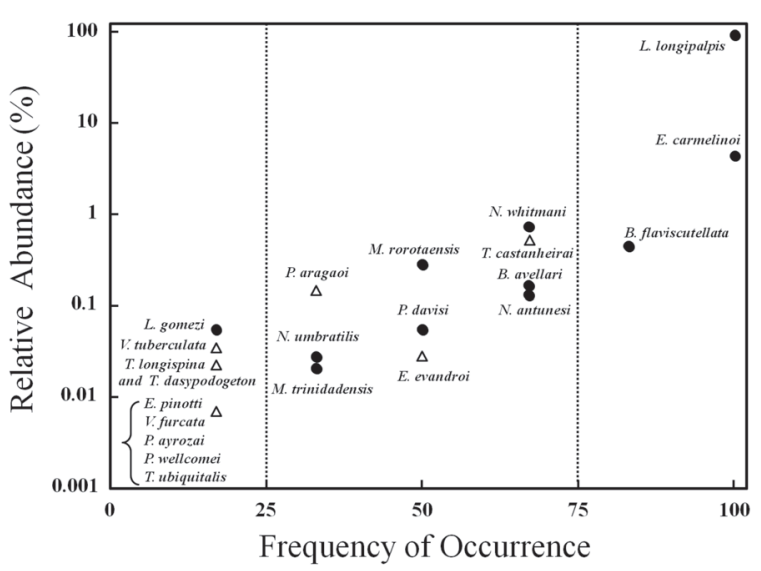

Figure 4 - Relative abundance of sand fly species and their frequency of occurrence along six years sampling (see text for details) in rural sites at Santarém municipality, state of Pará, Brazil. Species exclusive to rural sites and shared species were depicted by triangles and full circles, respectively.

generally indicated some proportionality between the number shared and exclusive species in each year (except for 1998). At least, nine sand fly individuals of four species were captured in urban areas of Ilhéus, state of Bahia, while fourteen sand fly species and 3,375 individuals were trapped in rural areas (Carvalho et al. 2010). At Porto Nacional, state of Tocantins, comparisons of Index of Species Abundance (ISA) pointed that $L$. longipalpis was the dominant species in these two areas and more numerous in urban areas (Vilela et al. 2008), as also observed in the present study. Aguiar and Medeiros (2003), in their habitat description of Brazilian species of sand flies, mentioned that E. carmelino $i$ is usually found in crops and livestock areas. In the Santarém survey, this sand fly species was very abundant in domiciles of urban areas, although it was the second mostly caught in rural areas. $N$. umbratilis is a species associated to forested areas, but it was captured in urban areas, though in low number of specimens. N. shawi, T. trichopyga and $B$. travassosi have also been associated to forest habitats such as burrows of armadillo and other wild animals according to Aguiar and Medeiros (2003). In the present study, these sand fly species were sporadically sampled and the scarce number of specimens was trapped in urban areas of Santarém. The authors also pointed that $V$. tuberculata and E. evandroi could be found in the inner and external walls of human domiciles; however these species were exclusive to rural areas of Santarém municipality.

At Santarém, the most frequent species during the study were L. longipalpis, E. carmelinoi and Bichromomyia flaviscutellata. The last two species presented lower relative abundance in relation to the first one, responsible by the great dominance index values in both rural and urban areas. In spite of epidemic AVL scenario at several cities of Brazil (Gontijo and Melo 2004), the main vector at northern

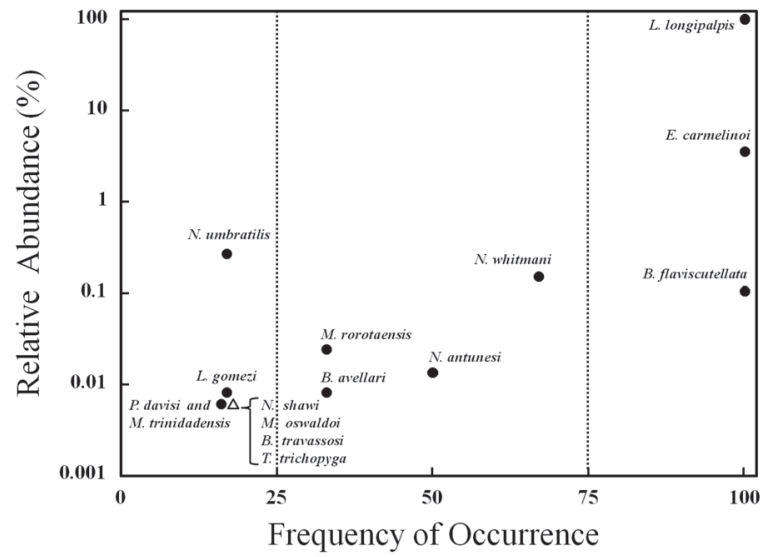

Figure 5- Relative abundance of sand fly species and their frequency of occurrence along six years sampling (see text for details) in urban sites at Santarém municipality, state of Pará, Brazil. Species exclusive to urban sites and shared species were depicted by triangles and full circles, respectively.

country, L. longipalpis, is an inherently sylvatic species, caught also in intact forests with no human domicile nearby (Lainson and Rangel 2005). The transmission cycle of AVL was initially restricted to wild and rural areas. However, nowadays it acquired complexity in urban areas, with a widespread epidemic events in São Luís, Natal, Aracaju, Boa Vista, Santarém, Belo Horizonte, Montes Claros, Cuiabá, and Campo Grande, where the disease has been associated to urbanization process (Gontijo and Melo 2004).

Higher absolute abundances of L. longipalpis in rural and urban areas of Santarém seemed to be a constant threat to AVL control. Previous entomological surveys also recorded high density of this species at several peripheral suburbs of Santarém (Senra et al. 1985). In these surveys, it was pointed that the species natural infection rate by Leishmania chagasi reached approximately seven per cent. In the same districts, AVL positive ratio was $32.3 \%$ in dogs, with 119 and 13 human documented cases in urban and rural areas, respectively (Senra et al. 1985). Another study conducted in 2002-2003, L. longipalpis and E. carmelinoi were the most abundant sand fly species $(59.7 \%$ and $35.5 \%$, respectively) in three outlying neighborhoods of Santarém city (Feitosa and Castellon 2009), where it was verified a higher number of sand fly individuals in the rainy season and at domiciles nearest of the remnant forests.

The main species captured and associated to ACV vectors were N. whitmani, B. flaviscutellata, Nyssomyia umbratilis, Psychodopygus davisi, P. wellcomei, and T. ubiquitalis. The first two Phlebotominae species seem to play major role in ACL transmission in Santarém due to their abundances (163 individuals of N. whitmani and 104 of B. flaviscutellata) compared to the other species. It is an evidence that these species are not becoming synanthropics, as observed in other 
regions of Brazil (Teodoro et al. 1999; Rêbelo 2001; Carvalho et al. 2010; Saraiva et al. 2011).

Leishmaniasis in Brazilian localities usually has shown a peridomiciliar transmission pattern, with adaptation of some vector sand fly species to modified environments, which also include domestic animals in the transmission cycle. However, cases of canine and human AVL in typical urban areas are now more frequent, suggesting a modification of the classic model of endemic area (Rêbelo et al. 1999; Teodoro et al. 1993). Higher disease prevalence in women and children and markedly domiciliary and peridomiciliary presence of vectors reveal a tendency of sand fly adaptation to man-made habitats, where they are responsible for transmission of Leishmania spp. (Santos et al. 2000; Marzochi and Marzochi 1997). Sand fly captures in henhouse, pigsty, dog kennel, and other animal shelters, showed that such animals act as attraction factor (Rêbelo 2001). Furthermore, some evidences also point out that phlebotomine insects have found ideal conditions to breed in these places or nearby them (Feitosa and Castellon 2009). Further studies in northern Brazil may consider the impact of forest removal (to human colonization) in the diversity and natural infection rates of sand flies (Pessoa et al. 2007), the differential infection rates in urban and rural areas and possible new breeding and resting habitats of these insects.

\section{ACKNOWLEDGMENTS}

We thank State Public Health Secretary of Pará (SESPA, $9^{\circ}$ Regional de Endemias) and the Pesquisador Visitante Program (Fiocruz/CNPq, no. 310507/2007-3) for financial support.

\section{REFERENCES}

Aguiar, G.M.; Medeiros, W.M. 2003. Distribuição regional e habitats das espécies de flebotomíneos do Brasil, p. 207-245. In: Rangel, E.F.; Lainson, R. (Eds.). Flebotomineos do Brasil. Fiocruz, Rio de Janeiro.

Alencar, J.E.; Pessoa, E.P.; Costa, O.R. 1962. Calazar em Santarém, estado do Pará, 1961. Endemias rurais. Revista Brasileira de Malariologia e Doenças Tropicais, 1: 371-374.

Barrett, T.V. 1993. Cutaneous leishmaniasis in Amazonas state, Brasil: eco-epidemiology and questions of control. Proceedings of Nacional Workshop Research and Control of Leishmaniasis in Brazil, Recife, 31-34.

Barrett T.V.; Freitas R.A.; Albuquerque M.I.C.; Guerrero J.H.C. 1996. Report on a collection of Lutzomyia sand flies (Diptera: Psychodidae) from the middle Solimóes (Amazonas, Brazil). Memórias do Instituto Oswaldo Cruz, 91: 27-35.

Campos, D.P. 2006. Map of Pará highlighting Santarém. www. commons. wikimedia.org. Accessed in July 2011.

Carvalho, S.M.S.; Santos, P.R.B.; Lanza, H.; Brandão-Filho, S.P. 2010. Diversity of Phlebotomine Sand Flies in Ilheus, State of Bahia, Brazil. Epidemiologia e Serviços de Saúde, 19: 239-244.
Colwell, R.K. 2009. EstimateS 8.2 User's Guide. Available at http:// viceroy.eeb.uconn.edu/estimates.

Feitosa, M.A.C; Castellón E.G. 2009. Flebotomíneos (Diptera: Psychodidae) na periferia de Santarém (PA). Estratificação horizontal e fatores agravantes para transmissão domiciliar de leishmanioses. Revista Colombiana de Ciências Animais, 1: 222-239.

Furtado, A.M.M; Macedo, M.R.A. 2006. As unidades de relevo e a expansão do sítio urbano da grande Santarém Microrregiáo do Médio Amazonas paraense - Estado do Pará: Observaçōes preliminares. In: Annals of VI Regional Conference on Geomorphology. Tropical and Subtropical Geomorphology: Processes, methods and techniques. Goiânia/GO, September 6-10.

Galati, E.A.B. 2003. Classificação de Phlebotominae. In E.F. Rangel, R. Lainson, Flebotomíneos do Brasil, Fiocruz, Rio de Janeiro, p. 23-51.

Gontijo C.M.F.; Melo M.N. 2004. Leishmaniose Visceral no Brasil: quadro atual, desafios e perspectivas. Revista Brasileira de Epidemiologia, 7: 338-349.

Gotelli, N. J.; Colwell, R. K. 2001. Quantifying biodiversity: procedures and pitfalls in the measurement and comparison of species richness. Ecology Letters, 4: 379-391.

Gray J.S.; Bjørgesæter A.; Ugland K.I. 2005. The impact of rare species on natural assemblages. Journal of Animal Ecology, 74: 1131-1139.

Lacerda, M.M. 1994. The Brazilian Leishmaniasis Control Program. Memórias do Instituto Oswaldo Cruz, 89: 489-495.

Lainson, R.; Rangel, E.F. 2005. Lutzomyia longipalpis and the ecoepidemiology of American visceral leishmaniasis, with particular reference to Brazil: a review. Memórias do Instituto Oswaldo Cruz, 100: 811-827.

Magurran, A.E. 2004. Measuring biological diversity. Oxford, Blackwell Science. 256p.

Maia-Elkhoury, A.N.S.; Alves, W.A.; Sousa-Gomes, M.L.; Sena, J.M.; Luna, E.A. 2008. Visceral leishmaniasis in Brazil: trends and challenges. Caderno de Saúde Pública, 24: 2941-2947.

Marzochi, M.C.A.; Marzochi, K.B.F. 1997. Leishmanioses em áreas urbanas. Revista da Sociedade Brasileira de Medicina Tropical, 30: $162-165$

Odum, P.E.; Barret, G.W. 2007. Fundamentos de Ecologia. 5. ed. São Paulo: Thomson. 612 pp.

Patz, J.A.; Daszak, P.; Tabor, G.M.; Aguirre, A.A.; Pearl, N.D.; Epstein, J.; Wolfe, N.D.; Kilpatrick, A.M.; Foufopoulos, J.; Molyneux, D.; Bradley, D.J. 2004. Unhealthy landscapes: policy recommendations on land use change and infectious disease emergence. Environmental Health Perspectives, 112: 1092-1098.

Pereira, M.A.; Spinola, P.M.; Martins, R.M.P.; Silva, S. R. 2000. Levantamento dos casos humanos de leishmaniose visceral humana na cidade de Santarém nos últimos 15 anos. Trabalho de conclusão de curso de ciências biológicas da Universidade Federal do Pará. Brasil.

Pessoa, F.A.C.; Medeiros, J.F.; Barrett, T.V. 2007. Effects of timber harvest on phlebotomine sand flies (Diptera: Psychodidae) in a production forest: abundance of species on tree trunks and 
prevalence of trypanosomatids. Memórias do Instituto Oswaldo Cruz, 102: 593-599.

Rebêlo, J.M.M. 2001. Freqüência horária e sazonalidade de Lutzomyia longipalpis (Diptera: Psychodidae: Phlebotominae) na ilha de São Luís, Maranhão, Brasil. Caderno de Saúde Pública, 17: 221-227.

Rebêlo, J.M.M.; Araújo, J.; Carvalho, M.; Oliveira, S.T.; Silva, F.S. 1999. Flebótomos (Diptera, Phlebotominae) da ilha de São Luis, zona do Golfão Maranhense, Brasil. Revista da Sociedade Brasileira de Medicina Tropical, 32: 247-53.

Ryan, L. 1986. Flebótomos do Estado do Pará, Brasil (Diptera: Psychodidae: Phlebotominae), Documento técnico n ${ }^{\circ} 1$, Instituto Evandro Chagas, Belém. 154 pp.

Santos, J.B.; Lauand, L.; Souza, G.S. 2000. Fatores sócio-econômicos e atitudes em relação à prevençâo domiciliar da leishmaniose tegumentar americana, em uma área endêmica do sul da Bahia, Brasil. Caderno de Saúde Pública, 16: 701-708.

Saraiva, L.; Andrade-Filho, J.D.; Falcão, A.L.; Carvalho, D.A.A.; Souza, C.M.; Freitas, C.M.; Lopes, C.R.G.; Moreno, E.C.; Melo, M.N. 2011. Phlebotominae fauna (Diptera: Psychodidae) in an urban district of Belo Horizonte, Brazil, endemic for visceral leishmaniasis: Characterization of favored locations as determined by spatial analysis. Acta Tropica, 117: 137-145

Senra, M.S.; Pimentel, P.S.R.; Souza, P.E.F.P. 1985. Leishmaniose visceral em Santarém/PA: Aspectos gerais do controle, inquérito sorológico em cães e tratamento dos casos humanos. Revista Brasileira de Malariologia e Doenças Tropicais, 37: 47-59.

Teodoro, U.; La Salvia, F.O.V.; Lima, E.M.; Misuta, N.M.; Verzignassi, T.G.; Ferreira, M.E.M.C. 1993. Observaçōes sobre o comportamento de flebotomíneos em ecótopos florestais e extraflorestais, em área endêmica de leishmaniose tegumentar americana, no norte do Estado do Parana, sul do Brasil. Revista de Saúde Pública, 27: 242-249.

Teodoro, U.; Kühl, J.B.; Thomaz-Soccol, V.; Barbosa, O.C.; Ferreira, M.E.M.C.; Lozovei, A.L.; Verzignassi, T.G.; Roberto, A.C.B.S. 1999. Environmental sanitation and peridomiciliar organization as auxiliary practices for the control of phlebotomines in Parana State, Southern Brazil. Brazilian Archives of Biology and Technology, 42: 307-314.

Vilela, M.L.; Azevedo, A.C.R.; Costa, S.M.; Costa, W.A.; Silva, D.M.; Grajauskas, A.M.; Moreira-de-Carvalho, B.; Paes, L.R.D.N.B.; Kozlowsky, D.; Rangel, E.F. 2008. Sand fly survey in the influence área of Peixe Angical Hydroelectric Plant, state of Tocantins, Brazil. 6th International Symposium on Phlebotomine Sandfies, Lima. 95 pp.

Young, D.G.; Duncan, M.A. 1994. Guide to the identification and geographic distribution of Lutzomyia sand flies in Mexico, the West Indies, Central and South America (Diptera: Psychodidae), Memoirs of the American Entomological Institute 54, Associated Publishers, American Entomological Institute, Gainesville. 881 pp.

Recebido em: 10/10/2011

Aceito em: 14/01/2012 